University for Business and Technology in Kosovo

UBT Knowledge Center

UBT International Conference

2017 UBT International Conference

Oct 27th, 4:45 PM - 7:15 PM

\title{
Reuse and regeneration of industrial zones
}

\author{
Rineta Jashari \\ University for Business and Technology, rineta.jashari@ubt-uni.net \\ Zana Prelvukaj \\ University for Business and Technology, zana.prelvukaj@ubt-uni.net \\ Faton Spahiu \\ University for Business and Technology, faton.spahiu@ubt-uni.net
}

Follow this and additional works at: https://knowledgecenter.ubt-uni.net/conference

Part of the Architecture Commons

\section{Recommended Citation}

Jashari, Rineta; Prelvukaj, Zana; and Spahiu, Faton, "Reuse and regeneration of industrial zones" (2017). UBT International Conference. 13.

https://knowledgecenter.ubt-uni.net/conference/2017/all-events/13

This Event is brought to you for free and open access by the Publication and Journals at UBT Knowledge Center. It has been accepted for inclusion in UBT International Conference by an authorized administrator of UBT Knowledge Center. For more information, please contact knowledge.center@ubt-uni.net. 


\title{
Reuse and regeneration of industrial zones
}

\author{
Rineta Jashari ${ }^{1}$, Faton Spahiu ${ }^{2}$, Zana Prelvukaj ${ }^{2}$ \\ UBT - Higher Education Institution, Prishtinë, Kosovë, \\ $\left\{\right.$ rineta.jashari $^{1}$; faton.spahiu ${ }^{2}$; zana.prelvukaj $\left.{ }^{2}\right\} @$ ubt-uni.net
}

\begin{abstract}
The research in this paper deals with the industrial heritage, analysis of industrial buildings built during XX century in Europe and in Kosovo, where as the case study is taken the city of Pristina and industrial revitalized buildings as good examples in Europe.

Industrial heritage is part of the cultural heritage that deals with the buildings and artifacts of the industry that are inherited from the past, and preserved for future generations, as a symbol and urban identity.

In Western European countries, the phenomenon of resurrection and industrial heritage is constantly growing and developing, in Southeast Europe is still a continuous process, while it has not yet started in Kosovo.

Pristina is one of the main cities of Kosovo, which in the first half of the 80's enjoyed a very good economic state, while from the war in 1999 and today it has faced problems of this nature as a result of the dysfunction of the industry in this field.

The main purpose of the research is to analyze industrial buildings built in the 20th century in Pristina, their current state, the potential of these buildings and the possibilities of reuse in the urban context.

The main focus of the study will be the possibility of adaptive reuse, revitalization for the benefit of the community and economic development.
\end{abstract}

Keywords: Kosovo, Urban regeneration, Industrial heritage, community, adaptive reuse

\section{Introduction}

As a heritage of the industrialized societies, the industrial complexes are experiencing dramatic changes for decades, which are reflected in the physical, the built environment of the cities. The subject of this paper is industrial brownfields, places and buildings that have lost their original purpose. Such complexes are despite of losing the original functionality, the inseparable ingredient of urban spaces, urban life and its rhythms. Industrial revolution In terms of social development, represents the greatest change of all, not only because of the altered methods of production, but also because of its impacts on all aspects of life. Due to the changes in global economy and the rapidly growing information society in the last decades, many industrial sites became excess in terms of primary functions. Today, being recognized as industrial heritage, they are seen as a potential development factor of the area instead of a neglected part of the past. Industrial heritage is a relatively new concept compared to the other established heritage buildings. [Cho, Shin, 2014].

1.1 Industrial heritage

The industrial heritage is an important element of modern identity." [Sandra Draskovic, April 2014]

"Industrial heritage consists of the remains of industrial culture which are of historical, technological, social, architectural or scientific value." (Charter, 2006) 
Industrial heritage is: inherited from the past and preserved for future generations as a symbol and urban identity.

Industrial heritage testifies to the development of industrial culture and it's historical, technological, social, architectural or scientific. Consists of buildings and machinery, mills, and factories, mines, and sites for processing and refining, warehouses and stores, places where energy is generated, as well as places used for social activities related to the industry such as housing, religious worship or education etc. [TICCIH 2003].

In Western Europe, there are many examples of successful adaptive reuse of industrial heritage and their role in the context of the development of new post-industrial.

A global map concerning the Industrial Heritage Sites shows composition for Industrial Heritage Sites as indicated by ICOMOS for all Heritage Sites.

Among 832 cultural heritage sites are on UNESCO's World Heritage list, about 45 sites represent industrial heritage (around 6\%).

\section{Adaptive reuse of industrial buildings}

Adaptive reuse is the act of finding a new use for a building. It is often described as a "process by which structurally sound older buildings are developed for economically viable new uses."

Preserving these industrial icons is an important part of maintaining the historic industrial character of a community.

Adaptive reuse should be the preferred strategy for an industrial when no other industrial option is available. And should always be favored over demolition and redevelopment.

Some of the more popular conversions of an industrial building are: museums, art studios, livework units, Offices, residential units, schools,

. Industrial heritage has a potential for changing the environmental image of industrial areas Because of: Historical significance, Architectural significance, Social significance and Cultural significance.

The continuity of the research is enriched with analytical method:

Analyzes of industrial buildings as a good adaptive reuse in Europe and Analyzes of industrial buildings built in the 20th century in Pristina, their current state and potentials of these buildings.

The previous function: Textile factory Erstein, France

New function: Multimedia Library in 2011

The objective of the project: urban integration

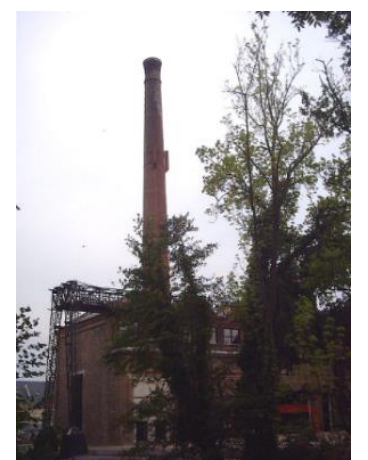

Fig 1-Before renewal

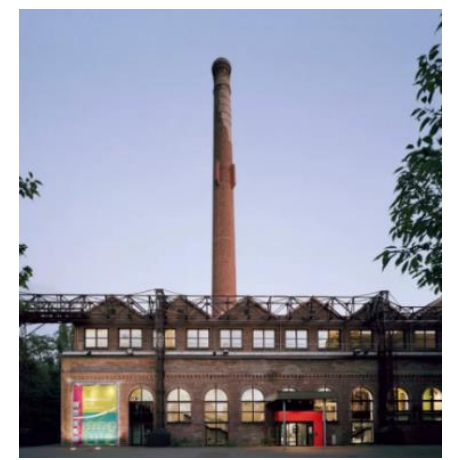

Fig 2 - After adaptation 
Silesian Museum, an old coal mine, Katowice Poland. Was established on January 23, 1929

In 2006 entered the State Register of Museums.

In 2015, the institution obtained its new head office in the modern complex of buildings in Katowice, ul. T. Dobrowolski 1.

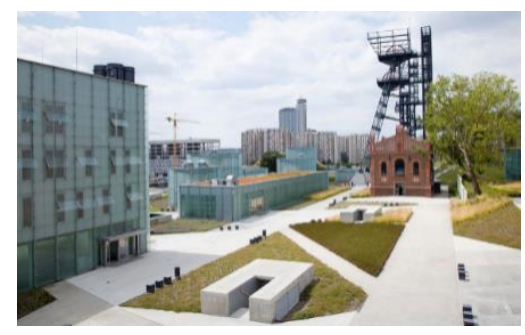

Fig.3-Coal mine, before renewal

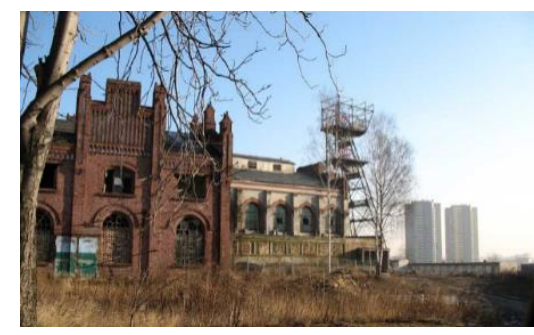

Fig.4-Adaptation of the remaining post- industrial facilities of the former coalmine.

\section{History of industrial area in Kosovo}

The industrial revolution in Kosovo has started later than in Europe. The beginnings of economic development with industrial facilities in Kosovo started in the century XX about 50 years ago, but only a small number of industrial branches of the manufacturing began the process.

First Industrial branches which began in beginning were 11, ferrous metallurgy, construction materials industry, non-metal industry, coal, wood, and textile.

In the 80's, industry in Kosovo peaked of progress and development, but after the political situation in the country which began in the 90 's, industry stalled in production, employment, development, and export. This situation continued until 1999 onwards when the war happened in Kosovo, where this occurrence caused a decrease in all industry in the state-social sector. (Industry in Kosovo, 2016)

After 1999 Kosovo had a decline dramatically in all areas. Among the most important factors that jeopardize the economic sustainability in the country was the stagnation of industry, weak environmental conditions and infrastructure, which as a result led to increased unemployment and social situation in Kosovo. (BANK, 2005)

Part of analyzes of industrial buildings built in the 20th century in Pristina, their current state and potentials of these buildings are taken factories "Tjerrtorja"-Textile factory and "Cigllana"-Brick factory .

With the uncontrolled and rapid development of cities, industrial facilities are integrated into urban areas. But on the other hand, this is a potential for the community, since these spaces can be used as shared spaces, in order to eliminate or decrease the degraded / brownfields.

As a good example of the revitalization of industrial facilities in Kosovo, is the factory of amortizes, which after privatization has been unworked, but is now rebuilt in the ambience and attractive location for everyone with its solution and re-utilization as private television and concert hall, where as a specialty of this area is urban regeneration and revitalization for the good of the community

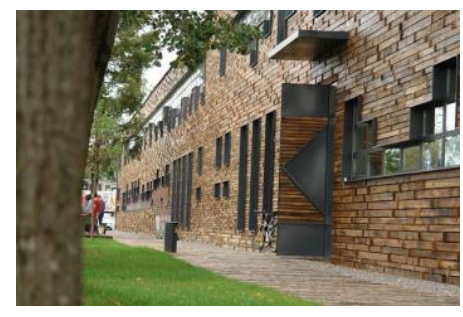

Fig 5.-Television Klan Kosovo, 2014 
The other good example of revitalization is Museum of Hidro central Prizren

Prizren's hydropower plant was the first to be built in Kosovo and started operating in 1929. It was built by an Austrian company to take advantage of the running river Lumbardh. The power plant has been active until 1973.

In 1979 the building was approved to become a Kosovo Electric Museum, with exhibition rooms, a restaurant and a bar.

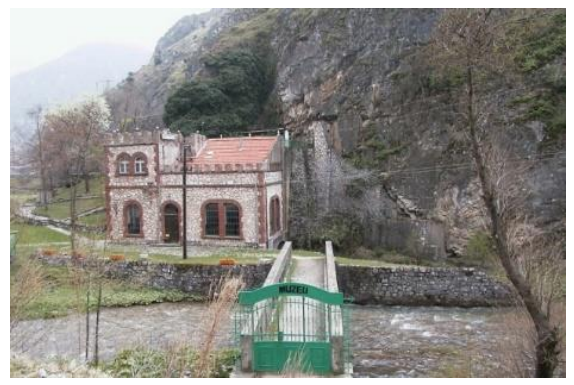

Fig.6-Museum of Hidro central Prizren

\section{Textile factory-“Tjerrtorja”}

- Location -Prishtina

- Year of construction- 1950

- Production :cotton and textile manufacturing factory

- Functional until the early postwar years

- Existing condition - unused

- Existing plant utilization-storage for various materials

- Is under protection by the Kosovo Heritage Institution after archaeological finds of terracotta figures
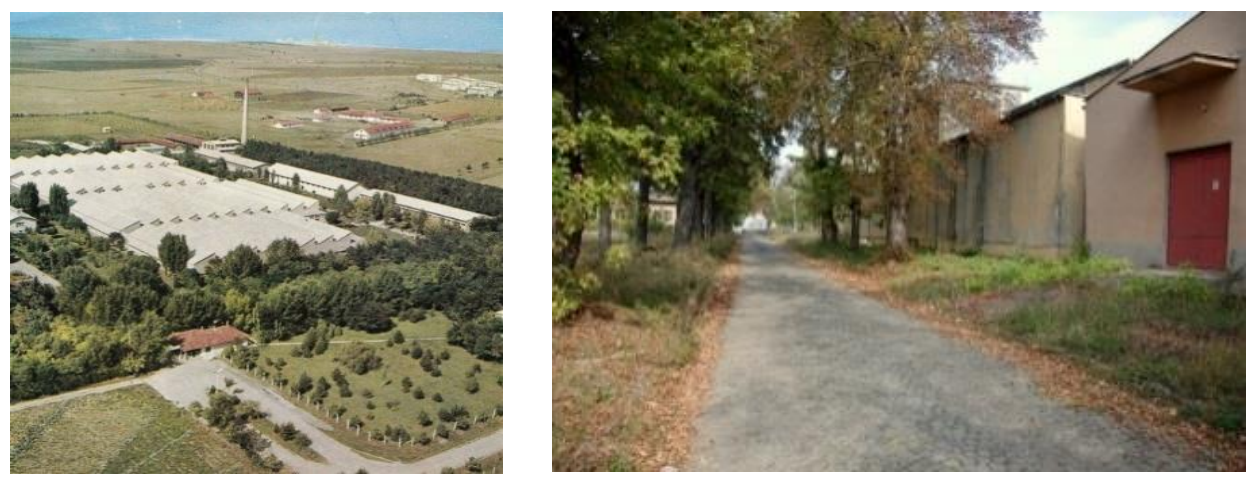

Fig.7.and Fig.8-Existing condition of factory

Factory 'Tjerrtorja' was identified in the 50s, known as the cotton and textile manufacturing factory.

Based on location it was named based on the location in the suburban neighborhood of Pristina, known as 'Calabria'. The trench as a factory for textile and cotton production was functional until after the war, where the new textile factory was built, and the old building remains out of function as a textile factory. 


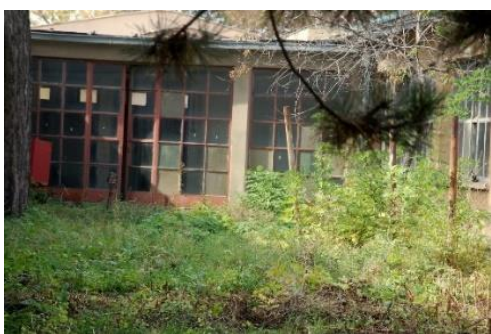

Fig.9- Existing situation

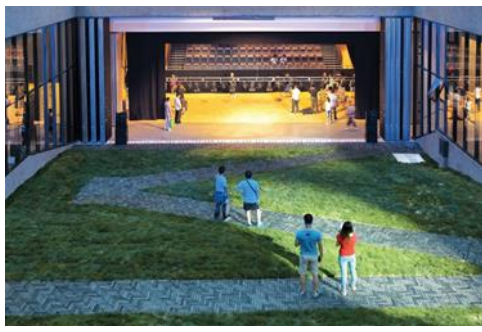

Fig.10-Adaptive reuse -proposal: "Theatre "

Preserving these industrial icons is an important part of maintaining the historic industrial character of a community. Changes in industrial practices have changed so dramatically in the last century that different regions have been prominent at different times and presently few regions dominate anymore as the industry has shifted globally.
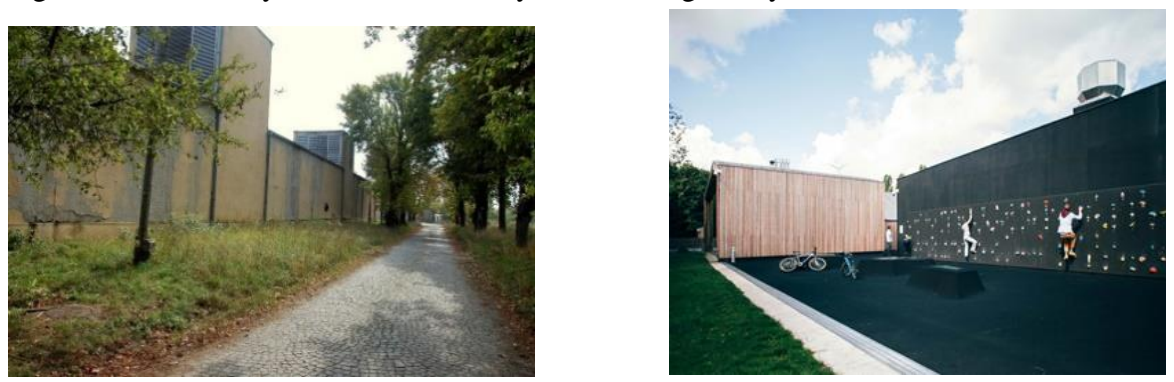

Fig.11 Existing situation

Fig.12 Proposal project

"Adaptive reuse -Youth

center"

Taking into account the urban extent in this area of Prishtina, which neighborhood includes 3 categories of urbanism (Low Housing, High Residential, Economic Zone and University Area), and in the absence of spaces and social facilities, the factory is meant to meet the needs of citizens as a social building without losing the values of industrial heritage.

Based on the questionnaire made with the residents of the neighborhood, about the factory refurbishment, they are not happy with the closure of the factory function and the usurpation of space by private company's .According to them, the results show that $90 \%$ of them are for the regeneration of this area and re-functionalizing for the good of the community.

Another aim is to restore the identity of this area, with the opportunity to re-use the space as a youth center and art work studios which they have given as a proposal.

\section{Brick Factory- "Tjegullorja" (Cigllana)}

The "Cigllana" clay and brick blocks production plant in Prishtina was built in the years 19401950. With the intervention of urban planning in 1983/84, the municipality announces a public tender for the demolition of the facility in its entirety. Yes, this year the central part of the factory was destroyed. The plant has been in operation until 2003/2004.

The factory today is in a state of inadvertence and is used for private interests of various companies.past to the present and even for the future. 


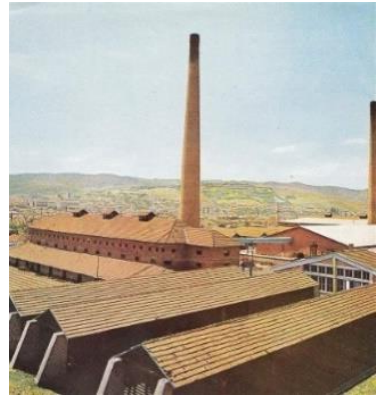

Fig.13 The old state of the factory-outside

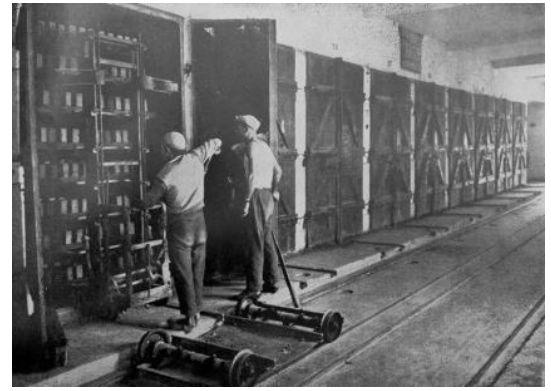

Fig.14-The old state of the factory-inside

Methods which are used in the research is quantitative method.

As part of the research we have taken the thoughts of residents who live in that area, in order to involve more accurate data.

\section{Results:}

Re function of the urban zone $95 \%$

Reusing the facility as a community center $90 \%$

Reusing the facility as a museum $80 \%$

After the study and the results with the inhabitants of the area, as a proposal was given the preservation of 3 factory buildings, which have historical and architectural value for the city, the facilities are proposed for re-use as Modern Art Museum integrating and modern facility, while two chimneys will be a landmark, where they express the value of the buildings that have been constructed and at the same time restore the identity of this area of the city.

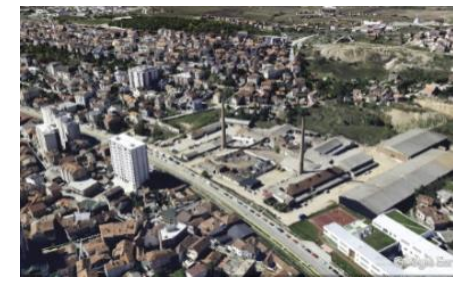

Fig.15-Existing situation

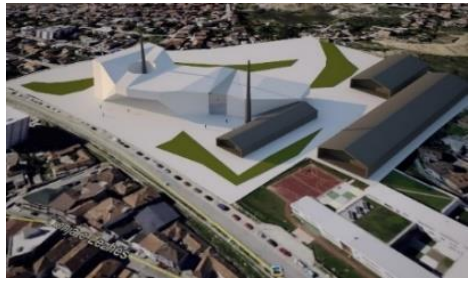

Fig.16-Adaptive reuse -museum and digital spaces

\section{Conclusion}

The city of Pristina needs adaptive reuse urban spaces, returns of values and urban identity in those areas. Surrounding area and urban development will benefit after reuse and regeneration of industrial zones. The community is ready for revitalization of degraded and unused areas for their own good. Through adaptive utilization, we can save also the green urban land. Moreover, the laws in function from the privatization agenda for industrial objects after privatization, they have their freedom from the private investor to decide for their own exploitation or demolition. The laws of the privatization agency AKP need to be changed as that the importance of industrial objects is very large and that these objects should be revitalized in cultural terms for the benefit of the communities rather than privatizing and destroying or losing 
their identity as it has been so far. The importance of these facilities is good for social, environmental and heritage reasons, so Kosovo should begin implementing these examples so that Kosovo society can benefit from these aspects.

\section{Recommendation}

- Protecting these areas from destruction without any criteria

- Implementation of project plans, for urban regeneration

- Change of privatization law

- Creation of institutions for the evaluation of industrial heritage, since Kosovo so far does not have such an institution.

\section{References}

1. Cho, M., Shin, S. 2014. Conservation or economization? Industrial heritage conservation in Incheon, Korea, Habitat International

2. https://www.slideshare.net/sandradraskovic/design-and-social-responsibility-industrialheritage

3. [Sandra Draskovic, April 2014]

4. https://www.icomos.org/18thapril/2006/nizhny-tagil-charter-e.pdf

5. http://whc.unesco.org/archive/ind-study01.pdf

6. http://whc.unesco.org/archive/ind-study01.pdf

7. https://sq.wikipedia.org/wiki/Struktura_e_Deg\%C3\%ABve_Industriale_n\%C3\%AB_Koso $\mathrm{v} \% \mathrm{C} 3 \% \mathrm{AB}$

8. http://siteresources.worldbank.org/INTKOSOVO/Data\%20and\%20Reference/20676217/P overty_Assesment_shqip.pdf

9. http://www.wikiwand.com/en/Erstein https://divisare.com/projects/167713-s-aa-floriantiedje-multimedia-library-in-an-old-factory-erstein-france Fig 1 and Fig 2

10. http://www.katowicethecity.com/building-permit-for-the-new-silesian-museum-approved/ Fig3 and Fig4

11. http://en.presstletter.com/2016/01/anarch-klan-kosova-television-2014/ Fig.5

12. http://www.erih.de/da-will-ich-hin/site/show/Sites/hydro-power-plant-electrical-museum/ Fig.6

13. https://muzeumslaskie.pl/pl/architektura-i-przestrzen/

14. http://dtk.rks-gov.net/tkk_objekti.aspx?id=8782 Fig 7 and Fig 8

15. https://divisare.com/projects/167713-s-aa-florian-tiedje-multimedia-library-in-an-oldfactory-erstein-france Fig. 9 and Fig. 10

16. http://dtk.rks-gov.net/tkk_objekti.aspx?id=8782 Fig.9 and Fig.11

17. https://www.facebook.com/PrishtinaOLD/photos/pb.400673566726339.2207520000.1495406017./901203950006629/?type=3\&theater Fig.13 and Fig.14

18. https://www.google.com/maps/@42.6668125,21.1596953,592a,35y,39.15t/data=!3m1!1e3 Fig. 15

19. http://www.wikiwand.com/en/Erstein

https://divisare.com/projects/167713-s-aa-florian-tiedje-multimedia-library-in-an-old-factoryerstein-france 